\section{The 2019 core-needle biopsy practice guidelines}

\author{
So Yeong Jeong, Jung Hwan Baek \\ Department of Radiology and Research Institute of Radiology, Asan Medical Center, \\ University of Ulsan College of Medicine, Seoul, Korea
}

We read with great interest the article published by Son et al. entitled "Distribution and malignancy risk of six categories of the pathology reporting system for thyroid core-needle biopsy in 1,216 consecutive thyroid nodules" [1]. In this article, the authors evaluated the distribution of thyroid nodules among the six categories of the pathology reporting system for thyroid core-needle biopsy (CNB), along with the range of malignancy risk of each category based on different diagnostic criteria for benignity in a large-population clinical cohort. They suggested that first-line CNB tended to yield a higher rate of conclusive results than second-line CNB with prior inconclusive fine-needle aspiration (FNA) results. The authors achieved excellent CNB results with a low complication rate. Thus, the data presented in this article furnish important support for the recommendations of the CNB guidelines developed by the Korean Society of Thyroid Radiology [2]. Moreover, this study provides useful results that may help patients with thyroid nodules to avoid repetitive FNA or diagnostic surgery involving CNB $[3,4]$. In particular, the results are valuable in that they provide the range of malignancy risk of each category based on different diagnostic criteria for benignity. It is very interesting that the final diagnosis of a benign nodule was made by three criteria [1]. We agree with the authors' opinion and personally prefer criterion 1.

Although this CNB study presented informative results from a large population, several issues should be considered. First, although the methodology of this study is clear, their pathologic report does not follow the 2019 clinical practice guidelines for CNB [5], in which the nondiagnostic category contains a diverse range of acellular specimens (e.g., acellular fibrotic tissue, acellular hyalinized tissue, cystic fluid only) [5]. Therefore, applying the 2019 clinical practice guidelines for CNB may result in a higher rate of nondiagnostic results. Second, we have a question regarding the high malignancy rate of category 1 in the authors' study, since it was most likely induced by the low incidence of a final diagnosis in category 1. Most of the patients were lost to follow-up or had no further diagnosis. Current guidelines suggest repeated biopsy for thyroid nodules with previous nondiagnostic results [6]. Finally, considering the paradigm shift in thyroid nodule diagnosis from focusing on the cancer detection rate to minimizing the unnecessary biopsy rate [7], we should strive to reduce the unnecessary biopsy rate in our daily practice.

In conclusion, Son et al. [1] reported valuable results regarding the distribution and malignancy risk of the six categories of the CNB pathology reporting system. Although these results are important and interesting, it is essential for operators who perform thyroid CNB to understand the new pathology reporting system [5] and the paradigm shift in thyroid nodule diagnosis.

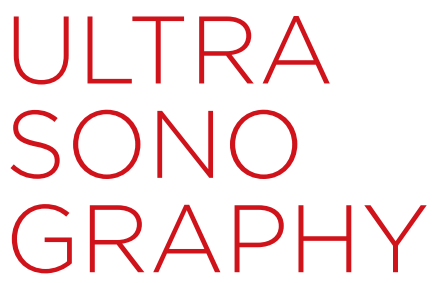

\section{LETTER}

https://doi.org/10.14366/usg.20053 pISSN: 2288-5919 • eISSN: 2288-5943 Ultrasonography 2020;39:311-312

Received: April 16, 2020

Revised: April 16, 2020

Accepted: April 23, 2020

Correspondence to: Jung Hwan Baek, MD, PhD, Department of Radiology and Research Institute of Radiology, Asan Medical Center, University of Ulsan College of Medicine, 88 Olympic-ro 43-gil, Songpa-gu, Seoul 05505, Korea

Tel. +82-2-3010-4348

Fax. +82-2-476-4719

E-mail: radbaek@naver.com
This is an Open Access article distributed under the terms of the Creative Commons Attribution NonCommercial License (http://creativecommons.org/ licenses/by-nc/4.0/) which permits unrestricted noncommercial use, distribution, and reproduction in any medium, provided the original work is properly cited.

Copyright (C) 2020 Korean Society of Ultrasound in Medicine (KSUM)

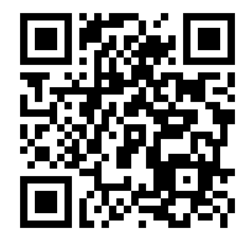

How to cite this article:

Jeong SY, Baek JH. The 2019 coreneedle biopsy practice guidelines. Ultrasonography. 2020 Jul;39(3):311-312. 
ORCID: So Yeong Jeong: https://orcid.org/0000-0003-4705-0008; Jung Hwan Baek: https://orcid.org/0000-0003-0480-4754

\section{Conflict of Interest}

No potential conflict of interest relevant to this article was reported.

\section{References}

1. Son HM, Kim JH, Kim SC, Yoo RE, Bae JM, Seo H, et al. Distribution and malignancy risk of six categories of the pathology reporting system for thyroid core-needle biopsy in 1,216 consecutive thyroid nodules. Ultrasonography 2020;39:159-165.

2. Na DG, Baek JH, Jung SL, Kim JH, Sung JY, Kim KS, et al. Core needle biopsy of the thyroid: 2016 consensus statement and recommendations from Korean Society of Thyroid Radiology. Korean J Radiol 2017;18:217-237.

3. Chung SR, Baek JH, Choi YJ, Sung TY, Song DE, Kim TY, et al. The role of core needle biopsy for the evaluation of thyroid nodules with suspicious ultrasound features. Korean J Radiol 2019;20:158165.

4. Hong MJ, Na DG, Kim SJ, Kim DS. Role of core needle biopsy as a first-line diagnostic tool for thyroid nodules: a retrospective cohort study. Ultrasonography 2018;37:244-253.

5. Jung CK, Baek JH, Na DG, Oh YL, Yi KH, Kang HC. 2019 Practice guidelines for thyroid core needle biopsy: a report of the Clinical Practice Guidelines Development Committee of the Korean Thyroid Association. J Pathol Transl Med 2020;54:64-86.

6. Haugen BR, Alexander EK, Bible KC, Doherty GM, Mandel SJ, Nikiforov YE, et al. 2015 American Thyroid Association management guidelines for adult patients with thyroid nodules and differentiated thyroid cancer: the American Thyroid Association Guidelines Task Force on Thyroid Nodules and Differentiated Thyroid Cancer. Thyroid 2016;26:1-133.

7. Ha SM, Baek JH, Na DG, Suh CH, Chung SR, Choi YJ, et al. Diagnostic performance of practice guidelines for thyroid nodules: thyroid nodule size versus biopsy rates. Radiology 2019;291:92-99. 